\title{
Population growth potential of rotifers from a high altitude eutrophic waterbody, Madín reservoir (State of Mexico, Mexico): The importance of seasonal sampling
}

\author{
Rosa Martha MORENO-GUTIÉRREZ, ${ }^{1}$ S.S.S. SARMA,${ }^{2 *}$ Alma Socorro SOBRINO-FIGUEROA, ${ }^{3}$ S. NANDINI ${ }^{2}$
}

${ }^{1}$ Programa de Doctorado en Ciencias Biológicas y de la Salud, Universidad Autónoma Metropolitana, Iztapalapa, Avenida San Rafael Atlixco No. 186, Colonia Vicentina, México, DF, CP 09340; ${ }^{2}$ Laboratorio de Zoología Acuática, Edificio UMF, Universidad Nacional Autónoma de México, Campus Iztacala, Av. de lo Barrios, no. 1, Los Reyes, Tlalnepantla, Edo. de México, CP 54090; ${ }^{3}$ Laboratorio Alejandro Villalobos, Departamento de Hidrobiología, Universidad Autónoma Metropolitana Iztapalapa, Avenida San Rafael Atlixco No. 186, Colonia Vicentina, México, DF, CP 09340, México

*Corresponding author: sarma@unam.mx

\begin{abstract}
To understand the population growth potential of different species of rotifers in nature, field collections through seasons are essential. We sampled zooplankton (and measured selected physicochemical variables) from the Madín reservoir, a high altitude eutrophic urban waterbody from Mexico, every month for a year. Qualitative analysis of zooplankton revealed 28 rotifer species and four cladoceran crustaceans plus one unidentified copepod. Cephalodella catellina $\left(1400\right.$ ind L $\left.{ }^{-1}\right)$, Horaella thomassoni $(550$ ind $\left.\mathrm{L}^{-1}\right)$, Conochilus dossuarius $\left(380\right.$ ind $\left.\mathrm{L}^{-1}\right)$ and Filinia longiseta $\left(25 \mathrm{ind}^{-1}\right)$ had higher peak density than other rotifers. Based on the concentrations of nitrates and phosphates, chlorophyll a levels or different diversity indices (e.g., Carlson, Shannon-Wiener, Pantle and Buck, Ejsmont-Karabin's TSI $\mathrm{Rot}_{\mathrm{t}}$ ), the waterbody is eutrophic to hypertrophic, depending on the season. In this waterbody we observed high densities of Aphanothece sp. which is a toxic picocyanobacterium. During the blooms of Aphanothece, we also recorded higher densities of $H$. thomassoni and $C$. catellina. Based on the gut contents we found that both these rotifer species feed on Aphanothece in this waterbody. This study thus suggests the potential growth of Horaella, Cephalodella, Conochilus and Filinia in this eutrophic reservoir containing blooms of Aphanothece.
\end{abstract}

Key words: Population dynamics; trophic state; Rotifera; species diversity; nutrients; chlorophyll-a.

Received: April 2018. Accepted: June 2018.

\section{INTRODUCTION}

The population growth potential of different species of rotifers is not fully explored. It is well-documented that rotifers are opportunistic species, which exploit resources and rapidly increase their abundance when conditions are favourable (Wallace et al., 2006). Since Edmondson's classic works on Keratella, the growth potential of rotifers has been estimated based on field samples (Edmondson, 1960, 1965). Under laboratory conditions, the population growth rates of rotifers are routinely estimated using different concentrations of one or two species of algae (Nandini et al., 2007; EspinosaRodríguez et al., 2014). These usually give data on the growth rates, which are of an order of magnitude higher than those from the field conditions. For example, the rotifer Brachionus plicatilis can be grown to densities as high as 25,000 ind $\mathrm{mL}^{-1}$ (Yoshimatsu and Hossain, 2014) which certainly does not occur in nature and the highest natural densities of $B$. plicatilis is about 50 ind $\mathrm{mL}^{-1}$ (Sarma, 1991; Filho et al., 2014). Therefore, population density of rotifers based on field collections reflect their natural growth potential while the maximal rates of population increase are reflected under test culture conditions.

Different studies on field collections of rotifers from both tropical and temperate conditions consistently show the dominance of a few species of rotifers. For example, in nature, one or more genera such as Anuraeopsis, Keratella, Kellicottia, Brachionus, Polyarthra, Liliferotrocha, Trichocerca, Synchaeta, Cephalodella, Conochilus, Lepadella, Lecane and Ptygura often become highly abundant. They reach $>1$ ind $\mathrm{mL}^{-1}$, at least in certain seasons (Duggan et al., 2002; Smith et al., 2009; Nandini et al., 2016; Wen et al., 2017). On the other hand, certain other rotifer genera such as Tripleuchlanis, Cyrtonia, Microcodides, Tetrasiphon, Lindia and Asplanchna rarely exceed 500 ind $\mathrm{L}^{-1}$ (Fontaneto and Melone, 2003; Wallace et al., 2006). It is generally thought that species that survive under a narrow range of environmental conditions do not show consistently high population abundances through different seasons (Moss, 2010). However, low densities of some rotifer genera mentioned earlier are not necessarily related to their narrow ranges of tolerances to environmental conditions, but other factors such as low intrinsic growth rates (Montero-Pau et al., 2014). For 
example, both Platyias and Plationus tolerate a similar range of $\mathrm{pH}$, dissolved oxygen, and temperature intervals (Sarma and Nandini, 2002). Yet, the natural densities of Plationus $\left(>16\right.$ ind $\left.\mathrm{L}^{-1}\right)$ are higher than those $\left(<6\right.$ ind $\left.\mathrm{L}^{-1}\right)$ of Platyias (Nandini et al., 2005; Muñoz-Colmenares et al., 2017). Many species of rotifers are bioindicators of water quality. For example, the saprobic index of Pantle and Buck (1955) and Sladecek's (1983) valences for different rotifer species are widely used to classify trophic status of freshwater bodies. On the other hand, even if rotifers are not identified to species level, their total density can be still used for inferring the trophic status (e.g., TSI $\mathrm{ROT}_{\text {, }}$ EjsmontKarabin, 2012).

To understand the population growth potential of different species of rotifers in nature, field collections through seasons are essential from as many waterbodies as possible. Only through one full year of zooplankton sampling effort, thus including all the seasons, we can estimate the peak population densities of different species present in a given waterbody (Orcutt and Pace 1984; Ramírez-García et al., 2002).

Seasonal variations of rotifers have been studied in different waterbodies in Mexico. However, almost all of them are based on large (e.g., lake Chapala) and historically (Lake Xochimilco), culturally (e.g., lake Paztcuaro) or for drinking water (e.g., Valle de Bravo) important waterbodies (De la Lanza and García, 2002). These studies form a basis for further research, but do not necessarily become a typical representation of small but perennial waterbodies (Alcocer and Bernal-Brooks, 2010). Here, we studied the monthly variations of rotifers from the Madín Reservoir during the period 2016-2017.

\section{METHODS}

The Madín reservoir is a high altitude $(2340 \mathrm{~m}$ above sea level) drinking water reservoir located in the State of Mexico (Mexico), in the northwest of Mexico City, at the border of the municipalities of Naucalpan de Juárez and Atizapán de Zaragoza (19³1'34'”N and $99^{\circ} 15^{\prime} 39^{\prime}$ 'W). It is an urban waterbody with a surface area of about 50 hectares. The maximum depth is around $50 \mathrm{~m}$. The waterbody is fed mainly by a stream of the Tlalnepantla River (Inclan, 1995). Water from this reservoir is consumed by two municipalities, Naucalpan and Atizapán. Due to human activities such as emission of pollutants, generated by industries and heavy vehicles, this waterbody is contaminated and at times the $\mathrm{pH}$ can be acidic, up to 5 (González-González et al., 2014). Also, since local administration does not have the necessary equipment for proper water treatment, this waterbody receives sanitary discharges from human settlements and industrial wastewaters containing heavy metals and pharmaceuticals.
To study the seasonal density of zooplankton from the Madín reservoir, monthly plankton samples were collected from five stations for a year (Fig. 1).

Sites 1 and 5 are in the middle of two hillsides, with an approximate depth of 2 meters; unlike site 1 , site 5 receives drainage from the human settlement around this area. Site 2 has an approximate depth of 10 meters and receives inflows from Tlalnepantla River; this site has some aquatic birds. Site 3 has an approximate depth of 1 $\mathrm{m}$ and is located on the edge of the dam; this also receives drainage from the township of Madín. Due to its shallow depth, this littoral region has terrestrial vegetation. Site 4 has the maximal depth among the sampling stations; it has a depth of $20 \mathrm{~m}$ in the pelagic zone of the waterbody. From each sampling station, we filtered $50 \mathrm{~L}$ of reservoir surface water through plankton net of $50 \mu \mathrm{m}$ mesh size.

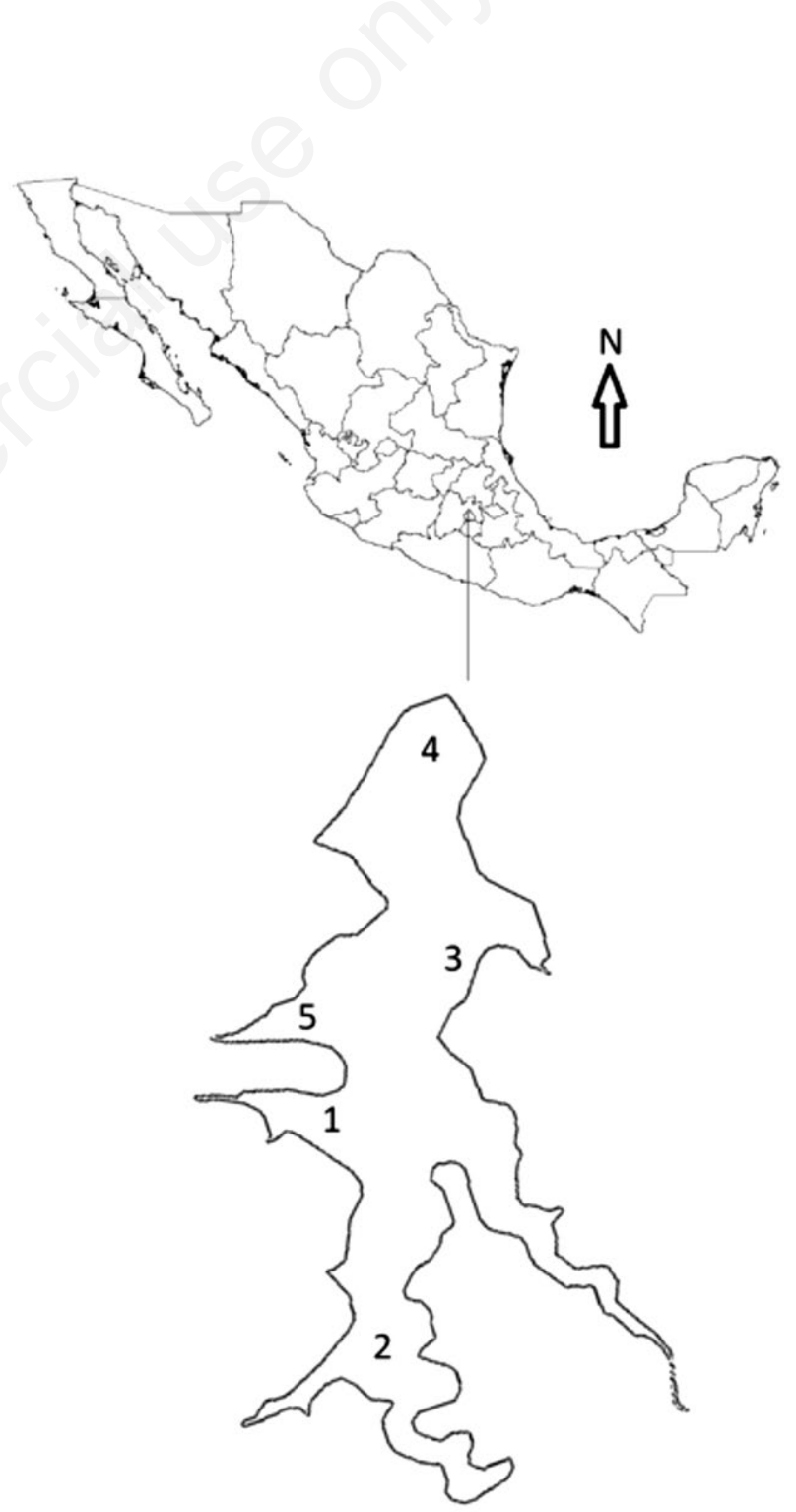

Fig. 1. Map of Madín reservoir with sampling stations 1 to 5 . 
The concentrated zooplankton samples were fixed in $4 \%$ formalin at the site itself. For some sampling stations, we also collected live samples for analysis in the laboratory. Also, at the time of zooplankton collection, we measured selected physicochemical variables of water (temperature, $\mathrm{pH}$, dissolved oxygen, Secchi transparency, alkalinity, phaeophytin-corrected Chlorophyll $a$, conductivity, bicarbonate, carbonate, phosphates (ascorbic acid method) and nitrates) using standard methods (Clesceri et al., 1998).

The zooplankton samples were later analysed in the laboratory using a stereomicroscope and a compound microscope. Zooplankton taxa were identified to as far as possible to species level using standard taxonomic literature (Koste, 1978; Wallace et al., 2016). For identification of rotifers, trophi was isolated, when needed using commercial sodium hypochlorite. Zooplankton quantification was carried out using 3-5 aliquot samples of $1 \mathrm{ml}$ from each collection using Sedgewick rafter counter and inverted microscope.

We used the following formula to derive species diversity index of Shannon-Wiener (Krebs, 1999).

$$
H^{\prime}=-\sum_{1}^{\mathrm{S}} p_{i \times \log _{2}} p_{i}
$$

Where $s=$ total number of species present in the sample, $p_{i}$ : the proportion of individuals of the species, and $i=$ total individuals.

Carlson's Trophic State Index (TSI) was derived using the data from Secchi disc transparency $\left(\mathrm{TSI}_{\mathrm{Sd}}\right)$, chlorophyll $a$ (TSI chl , and total phosphorus concentration (TSI ${ }_{\mathrm{TP}}$ ) (Carlson, 1977). Total $\mathrm{PO}_{4}$ was converted to total $\mathrm{P}$ using the following: Total $\mathrm{P}=$ Total $\mathrm{PO}_{4}(\mathrm{mg} / \mathrm{L}) \mathrm{X}$ 0.3262 .

$\mathrm{TSI}=\left[\mathrm{TSI}_{\mathrm{TP}}+\mathrm{TSI}_{\mathrm{chl}}+\mathrm{TSI}_{\mathrm{sd}}\right] / 3$, where, $\mathrm{TSI}_{\mathrm{chl}}=9.81 \ln$ Chlorophyll $a\left(\mu \mathrm{g} \mathrm{L}^{-1}\right)+30.6$; TSI $_{\mathrm{Sd}}=60-14.41$ In Secchi depth (m); $\mathrm{TSI}_{\mathrm{TP}}=14.42$ In Total Phosphorous $(\mu \mathrm{g} \mathrm{L}$ $\left.{ }^{1}\right)+4.15$ (Osgood, 1982).

The Saprobic index (S) was calculated using the formula proposed by Pantle and Buck (1955). Here $S=\Sigma$ (s.h) / $\Sigma h$, where $S$ is the saprobic index of Pantle and Buck (1955); $s$ is the valence of each rotifer species (Sladecek, 1983); $h$ is the relative frequency (1, rare; 3 , common; 5; abundant). The saprobic index $S$ is based on the following classification scale: $1.0-1.5$, oligosaprobic; 1.6-2.5, $\beta$-mesosaprobic; $2.6-3.5, \alpha$-mesosaprobic; 3.64.4 , polysaprobic.

When rotifers dominate aquatic systems and their density is known, then the trophic state index proposed by Ejsmont-Karabin (2012) is useful: $\mathrm{TSI}_{\mathrm{Rot}}=5.38 \mathrm{ln}$ $(\mathrm{N})+19.28$, where, $\mathrm{N}=$ total rotifer density $\left(\right.$ ind $\left.^{-1}\right)$. When $\mathrm{TSI}_{\mathrm{ROT}}=<45$ mesotrophic; between 45-55: mesoeutrophic; between 55-65: eutrophic and >65: hypertrophic. Additionally, using the total rotifer density, trophic state was derived using the following (EjsmontKarabin, 1995; May and O'Hare, 2005; Ejsmont-Karabin, 2012): Total rotifer density $=<500$ ind $\mathrm{L}^{-1}$ : oligotrophic; between 500-1000 ind $\mathrm{L}^{-1}$ : mesotrophic; between 10002500 ind $\mathrm{L}^{-1}$ : eutrophic and between $3000-4000$ ind $\mathrm{L}^{-1}$ : hypertrophic conditions.

To rank the dominant zooplankton species, we conducted Olmstead-Tukey analysis using species frequency and abundance data (Sokal and Rohlf, 2012). After performing Pearson correlations between the dominant rotifer species and the physicochemical variables, we conducted Canonical Correspondence Analysis (CCA) between the chosen abiotic and biotic factors to visualise the effect of different variables on rotifer taxa.

\section{RESULTS}

Data on the selected physicochemical variables showed considerable variations through seasons of dissolved oxygen (3-19 $\left.\mathrm{mg} \mathrm{L}^{-1}\right)$, conductivity $(93-139 \mu \mathrm{S}$ $\mathrm{cm}^{-1}$ ) and $\mathrm{pH}$ (7 to 10$)$. Temperature varied from 14 to $24^{\circ} \mathrm{C}$ depending on the season. Nitrates varied from 0.4 to $43.1 \mathrm{mg} \mathrm{L}^{-1}$ while phosphates from 0.17 to $3.6 \mathrm{mg} \mathrm{L}^{-1}$.

Mean annual concentrations of bicarbonates and carbonates from all stations varied from 13 to 266 and 0 to $48 \mathrm{mg} \mathrm{L}^{-1}$, respectively. Carlson index of trophic state showed the values ranged from 61 to 90 for the Station 5 and for the rest of the stations, the index was within this range (Tab. 1). Zooplankton was mainly composed of rotifers (28 taxa) while crustaceans were represented by four taxa and cyclopoids n.d. (Tab. 2). Keratella tropica, Euchlanis lyra, Lecane bulla, Cephalodella catellina, Conochilus dossuarius and Filinia longiseta were present for at least six months in this waterbody. The rare species Horaella thomassoni was present during five months.

Mean annual average density of most rotifer species were $<10$ ind $\mathrm{L}^{-1}$. However, H. thomassoni, C. dossuarius and C. catellina were at the mean annual density of 5070 ind $\mathrm{L}^{-1}$. Fig. 2A shows the seasonal changes in the densities of $C$. catellina which had a single peak abundance of 1400 ind $\mathrm{L}^{-1}$ from the sampling station 4 during November and for the rest of the stations during this period, the values were $200-400$ ind $\mathrm{L}^{-1}$.

H. thomassoni showed population densities of up to 550 ind $\mathrm{L}^{-1}$ during August and November from the stations 1 and 4, respectively (Fig. 2B). C. dossuarius had higher densities mainly during August to October months (mean 300 ind $\mathrm{L}^{-1}$ ) (Fig. 2C). F. longiseta occurred in much lower densities (up to 32 ind $\mathrm{L}^{-1}$ ) in all the sampling stations during the study period (Fig. 2D).

The relation between species frequency and density (Olmstead-Tukey) showed that few rotifer taxa were common while rare species constituted more than $50 \%$. 
Tab. 1. Selected physico-chemical and biotic variables (range, min. and max. values) of Madín reservoir from five sites during June 2016-May 2017.

\begin{tabular}{|c|c|c|c|c|c|}
\hline \multirow[t]{2}{*}{ Variable } & \multicolumn{5}{|c|}{ Sampling stations } \\
\hline & 1 & 2 & 3 & 4 & 5 \\
\hline $\mathrm{DO}\left(\mathrm{mg} \mathrm{L}^{-1}\right)$ & $3.3-10.6$ & $2.2-13.1$ & $3.3-16.2$ & $3.4-15.4$ & $4.8-19.2$ \\
\hline Temperature $\left({ }^{\circ} \mathrm{C}\right)$ & $14.7-21.1$ & $14.7-22.5$ & $15.3-23.7$ & $15.3-24.4$ & $16-24$ \\
\hline Conductivity $\left(\mu \mathrm{S} \mathrm{cm}^{-1}\right)$ & $120-248$ & $139-238$ & $134-238$ & $128-248$ & $136-257$ \\
\hline $\mathrm{pH}$ & $6.9-9.6$ & $7.3-9.7$ & $7.4-10.2$ & $7.5-10.1$ & $7.5-10.1$ \\
\hline Bicarbonate $\left(\mathrm{mg} \mathrm{L}^{-1}\right)$ & $0-100$ & $32-964$ & $17-90$ & $0-90$ & $18-90$ \\
\hline Carbonate $\left(\mathrm{mg} \mathrm{L}^{-1}\right)$ & $0-40$ & $0-42$ & $0-61$ & $0-58$ & $0-42$ \\
\hline $\mathrm{NO}_{3}^{-}\left(\mathrm{mg} \mathrm{L}^{-1}\right)$ & $0.60-16.40$ & $0.90-8.80$ & $0.40-25.60$ & $0.50-32.40$ & $1.08-43.10$ \\
\hline $\mathrm{PO}_{4}^{3-}\left(\mathrm{mg} \mathrm{L}^{-1}\right)$ & $0.36-1.45$ & $0.34-2.10$ & $0.32-3.60$ & $0.17-1.00$ & $0.25-1.35$ \\
\hline Chl $a\left(\mu \mathrm{g} \mathrm{L}^{-1}\right)$ & $14.2-348.1$ & $7.8-212.6$ & $2.4-275.8$ & $6.8-759.3$ & $5.9-928.8$ \\
\hline Hardness $\left(\mathrm{CaCO}_{3} \mathrm{mg} \mathrm{L}^{-1}\right)$ & 6-120 & $4-140$ & $4-132$ & $2-112$ & $0-116$ \\
\hline Secchi $(\mathrm{cm})$ & $37-147$ & $23-113$ & $22-93$ & $19-15$ & $21-101$ \\
\hline Carlson index & $66.5-80.3$ & $63.9-78.8$ & $70.1-79.2$ & $64.0-81.8$ & $61.1-90.0$ \\
\hline $\mathrm{TSI}_{\mathrm{ROT}}$ & $17-56$ & $18-52$ & $21-55$ & $18-60$ & $26-56$ \\
\hline
\end{tabular}
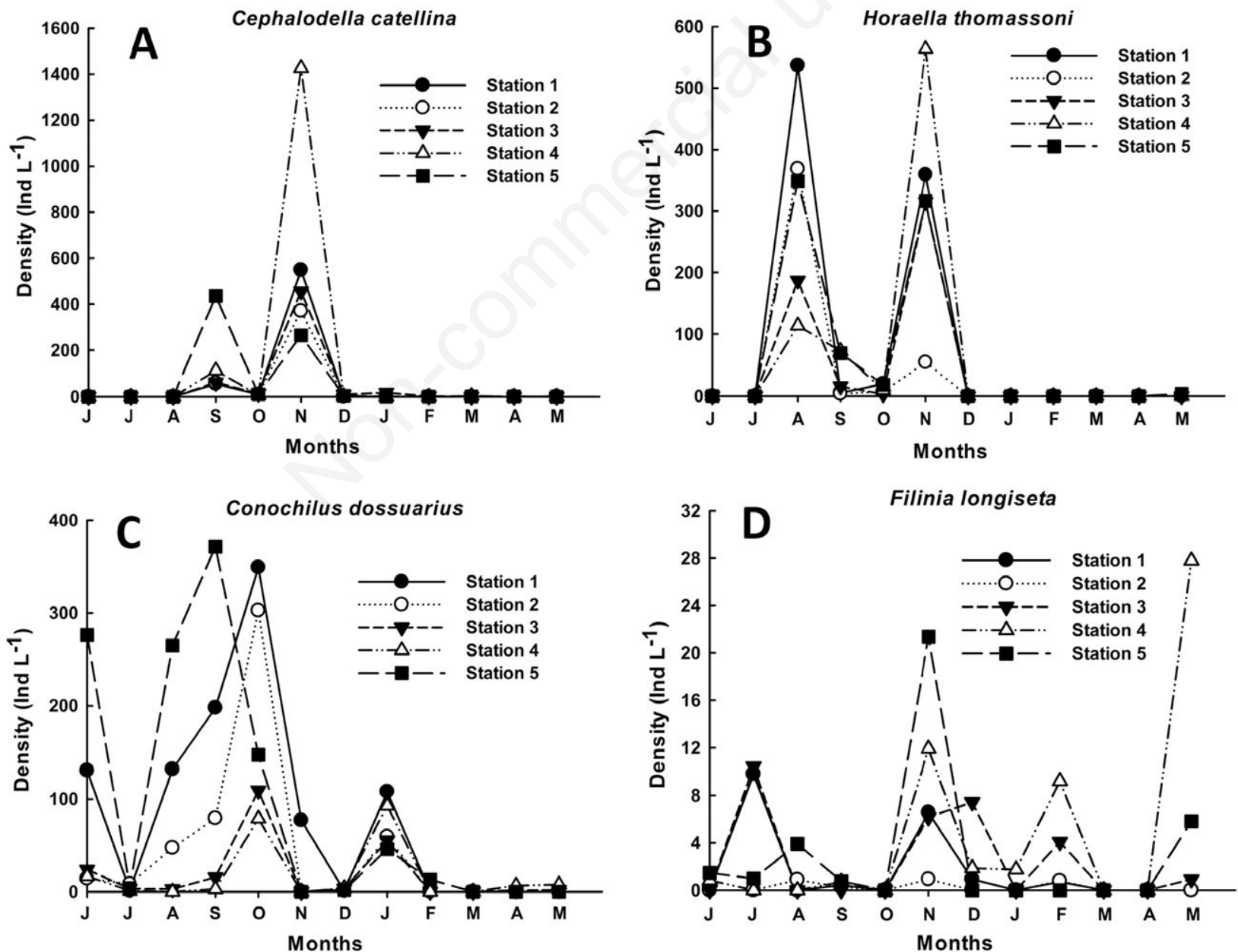

Fig. 2. Seasonal changes in the densities of Cephalodella catellina (A), Horaella thomassoni (B), Conochilus dossuarius (C) and Filinia longiseta from the Madín reservoir at different sampling stations. Note the differences on the Y-axis scale. 
Tab. 2. List of zooplankton species observed from the Madín reservoir during June 2016-May 2017. Shown are the presence (X) and absence (-) of rotifer species during the sampling period.

\section{Taxa}

\section{Months}

\section{Rotifera}

Family: Brachionidae

Brachionus angularis (Gosse, 1851)

Brachionus caudatus Barrois \& Daday, 1894

Brachionus havanaensis Rousselet, 1911

Brachionus quadridentatus (Hermann, 1783)

Kellicottia bostoniensis (Rousselet, 1908)

Keratella americana Carlin, 1943

Keratella cochlearis (Gosse, 1851)

Keratella tropica (Apstein, 1907)

Platyias quadricornis (Ehrenberg, 1832)

$\begin{array}{lllllllllllll}- & - & \mathrm{X} & - & - & - & - & - & - & - & - & - \\ - & \mathrm{X} & - & \mathrm{X} & - & - & - & - & - & - & - & - \\ \mathrm{X} & - & \mathrm{X} & \mathrm{X} & \mathrm{X} & - & \mathrm{X} & - & - & - & - & - \\ \mathrm{X} & - & - & \mathrm{X} & \mathrm{X} & \mathrm{X} & \mathrm{X} & - & - & - & - & - \\ \mathrm{X} & - & - & - & - & - & - & - & - & - & - & - \\ - & - & - & \mathrm{X} & - & - & - & - & - & - & - & \mathrm{X} \\ \mathrm{X} & \mathrm{X} & - & - & - & \mathrm{X} & \mathrm{X} & - & & \mathrm{X} & - & \mathrm{X} \\ - & - & - & \mathrm{X} & - & - & \mathrm{X} & \mathrm{X} & \mathrm{X} & \mathrm{X} & - & \mathrm{X} \\ - & - & - & - & \mathrm{X} & \mathrm{X} & \mathrm{X} & - & - & - & - & -\end{array}$

Family: Euchlanidae

Euchlanis dilatata Ehrenberg, 1832

Euchlanis lyra Hudson, 1886

Family: Mytilinidae

Lophocharis salpina (Ehrenberg, 1834)

Family: Colurellidae

Colurella uncinata (Müller, 1773)

Family: Lepadellidae

Lepadella acuminata (Ehrenberg, 1834)

Lepadella patella (Müller, 1773)

Family: Lecanidae

Lecane bulla (Gosse, 1851)

Lecane closterocerca (Schmarda, 1859)

Lecane hamata (Stokes, 1896)

Lecane tenuiseta Harring, 1914

$\begin{array}{llllllllllll}- & - & - & - & \mathrm{X} & - & - & - & - & - & - & - \\ - & - & - & - & - & \mathrm{X} & \mathrm{X} & \mathrm{X} & - & \mathrm{X} & \mathrm{X} & \mathrm{X}\end{array}$

Family: Notommatidae

Cephalodella catellina (Müller, 1786)

Cephalodella gibba (Ehrenberg, 1830)

Family: Trichocercidae

Trichocerca $s p$.

Family: Asplanchnidae

Asplanchna brightwelli (Gosse, 1850)

Family: Flosculariidae

Sinantherina sp.

Family: Conochilidae

Conochilus dossuarius (Hudson, 1875)

Family: Filiniidae

Filinia longiseta (Ehrenberg, 1834)

Family: Trochosphaerldae

Horaella thomassoni Koste, 1973

Family: Collothecidae

Collotheca sp.

\section{Cladocera}

Family: Daphniidae

Daphnia ambigua Scourfield, 1947

Family: Moinidae

\begin{tabular}{llllllllllllll} 
Moina micrura Kurz, 1874 & X & X & X & - & - & - & - & - & - & - & - & X \\
$\begin{array}{l}\text { Family: Sididae } \\
\text { Diaphanosoma birgei Korinek, } 1981\end{array}$ & X & X & X & X & X & X & - & - & - & - & - & - \\
\hline
\end{tabular}

\section{Copepoda}

Family: Diaptomidae

$\begin{array}{lllllllllllllllll}\text { Mastigodiaptomus albuquerquensis (Herrick, 1895) } & \mathrm{X} & \mathrm{X} & \mathrm{X} & \mathrm{X} & \mathrm{X} & \mathrm{X} & \mathrm{X} & \mathrm{X} & \mathrm{X} & \mathrm{X} & \mathrm{X} & \mathrm{X}\end{array}$ cyclopoids n.d. (as nauplii and adults)

$\begin{array}{llllllllllll}X & X & X & X & X & X & X & X & X & X & X & X \\ X & X & X & X & X & X & X & X & - & - & - & -\end{array}$


From all the sampling stations, C. catellina and $H$. thomassoni were dominant; there were few common species. Site 3 had the highest number (10) of dominant species while Site 2 had the lowest (3). In addition, there were a few temporal species (Fig. 3).
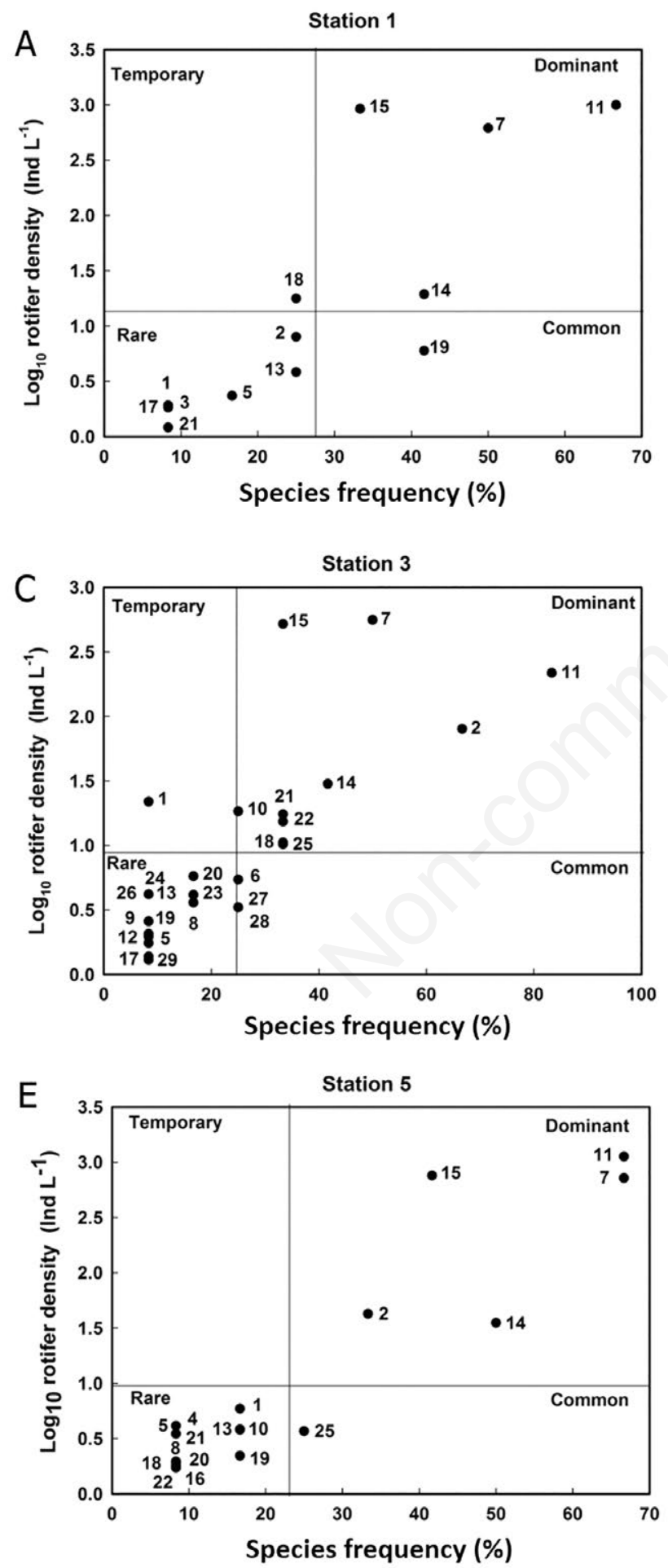

Results from the CCA revealed that Horaella thomassoni, Filinia longiseta, C. catellina and C. dossuarius were correlated with one or more physicochemical variables (Fig. 4). For example, $C$. dossuarius negatively related to Secchi transparency, while $F$. longiseta with bicarbonates.
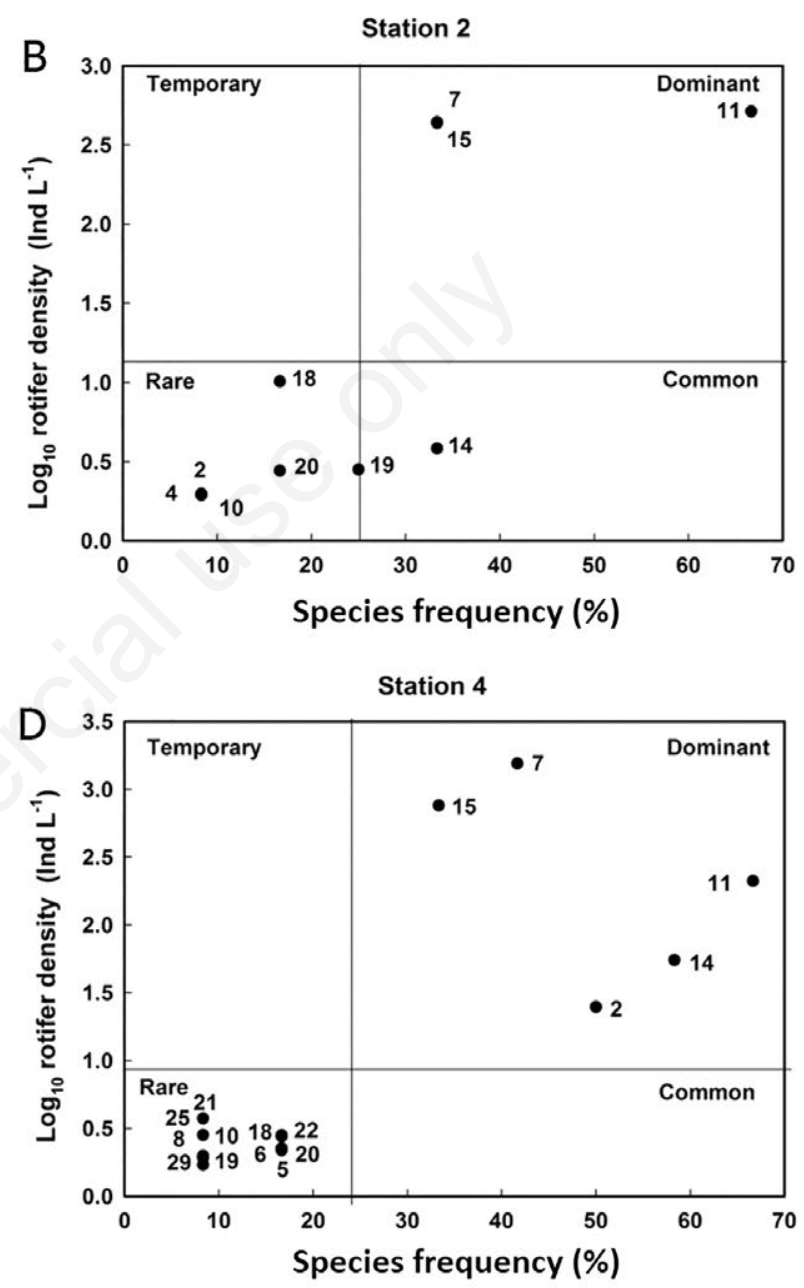

Fig. 3. Olmstead-Tukey test for density and frequency of zooplankton from the Madín reservoir (June 2016 to May 2017) from the sampling stations 1 to 5 . The numbers indicate the species: 1, Asplanchna brightwellii; 2, Bdelloids; 3, Brachionus angularis; 4,. Brachionus caudatus; 5, Brachionus havanaensis; 6, Brachionus quadridentatus; 7, Cephalodella catellina; 8, Cephalodella gibba; 9, Collotheca sp.; 10, Colurella uncinata; 11, Conochilus dossuarius; 12, Euchlanis dilatata; 13, Euchlanis lyra; 14, Filinia longiseta; 15, Horaella thomassoni; 16, Kellicottia bostoniensis; 17, Keratella americana; 18, Keratella cochlearis; 19, Keratella tropica; 20, Lecane bulla; 21, Lecane closterocerca; 22, Lecane hamata; 23, Lecane tenuiseta; 24, Lepadella acuminata; 25, Lepadella patella; 26, Lophocharis salpina; 27, Platyias quadricornis; 28, Sinantherina sp.; 29, Trichocerca sp. 
Shannon-Wiener diversity index ranged from close to zero to 2.3 bits ind $^{-1}$ depending on the sampling station and month. In general Station 2 had the lowest species diversity in all seasons, while Station 3 had the highest. December month had the highest species diversity index for four stations (Fig. 5). Saprobic index of Pantle and Buck varied from 1.0 to 2.4 depending on the sampling station and the season. In general stations, 1 to 4 was beta mesosaprobic, while station 5 was predominantly oligosaprobic (Fig. 6).

The $\mathrm{TSI}_{\mathrm{ROT}}$ index in this waterbody varied from 17-60 depending on the sampling station and the month. In general for all the stations, November month had the highest $\mathrm{TSI}_{\mathrm{ROT}}$ index, while for February to April, these values were lowest (Tab. 1).

\section{DISCUSSION}

The range of physicochemical variables recorded in this study is known in some other waterbodies of this region (De la Lanza and García, 2002). For example, in high altitude regions of central Mexico, water temperature ranges from $<10$ to $>24^{\circ} \mathrm{C}$ (Alcocer and Bernal-Brooks, 2010). In Site 1, we observed near neutral pH (6.9), but it was as high as 10 in other stations. Previous studies have shown that the $\mathrm{pH}$ of this waterbody was acidic (Inclan, 1995; González-González et al., 2014). Our study indicated that $\mathrm{pH}$ from all sampling stations during most part the year was on the basic range suggesting that some improvements did occur in this waterbody due to

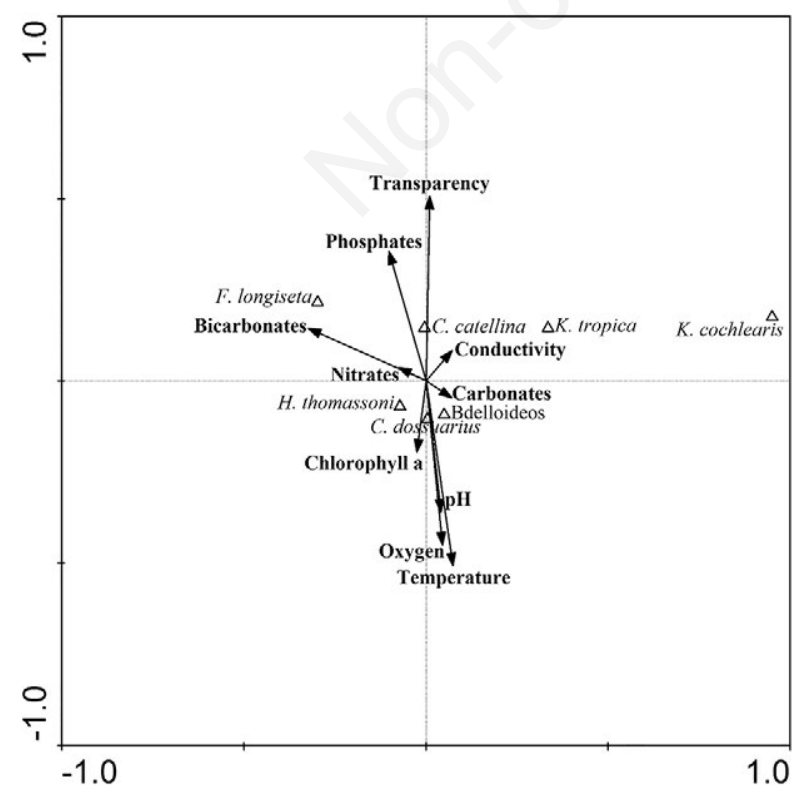

Fig. 4. Canonical correspondence analysis of rotifers from the Madín reservoir with the abiotic and biotic variables. governmental intervention, including regulation of vehicular traffic.

The previously mentioned study also showed the presence of pharmaceuticals such as nonsteroidal antiinflammatory drugs at concentrations from 0.18 to 4.51 ng L ${ }^{-1}$ (González-González et al., 2014). However, using a similar method employed in a previous study, we did not find these pharmaceuticals at detection levels. Although the disorderly urban growth around this waterbody continues to discharge the wastewater, some regulatory laws have been enforced on the local

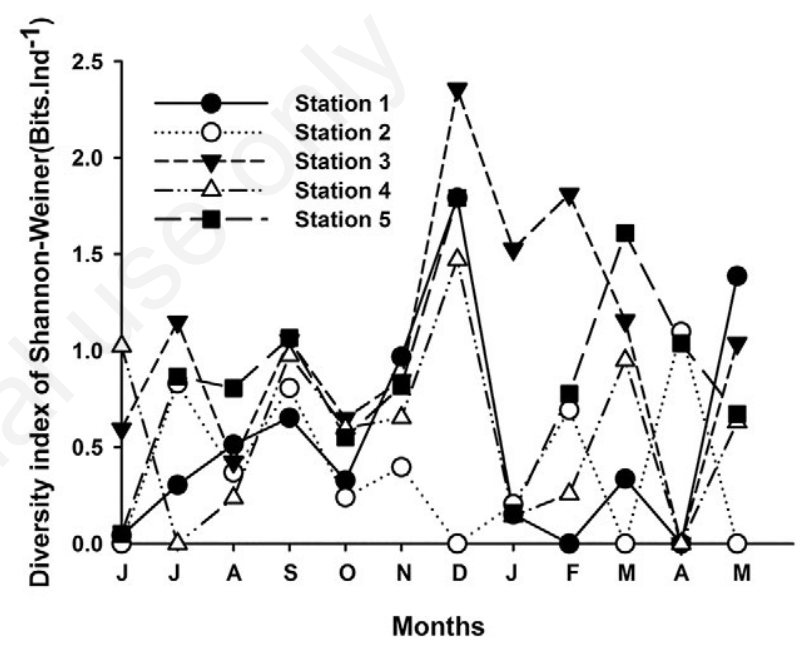

Fig. 5. Shannon-Wiener species diversity index from the Madín reservoir in relation to zooplankton collection period from different sampling stations.

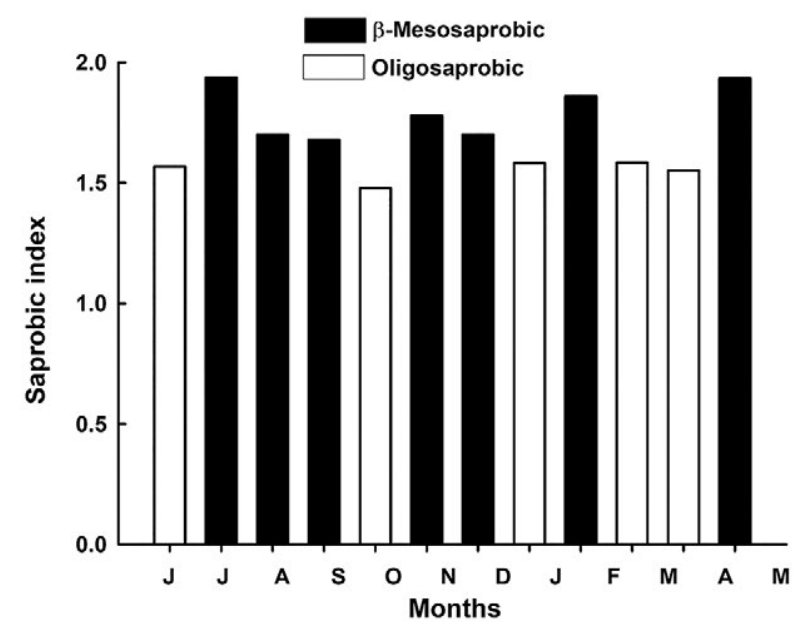

Fig. 6. Saprobic index from the Madín reservoir in relation to zooplankton collection period based on the mean values of five sampling stations. 
inhabitants. This is further supported by the fact that towards the end of 2013 there was an intense effort to clean-up the reservoir by the local administration to offer drinking water from this waterbody. Similarly, in a nearby waterbody, Lake Xochimilco (Mexico City) once had high levels of triclosan, an endocrine disruptor (DuranAlvarez et al., 2015) but after a few years, its concentrations were undetectable in the same waterbody (González-Pérez et al., 2018).

Carbonates and bicarbonates were in low or undetectable levels during certain months (June and December). The nitrate levels were not high $\left(<2 \mathrm{mg} \mathrm{L}^{-1}\right)$, except in the summer months (May-June), to cause mortality to zooplankton. For example, the $\mathrm{LC}_{50}$ for Daphnia magna is about $460 \mathrm{mg} \mathrm{L}^{-1}$ (Camargo et al., 2005). However, phosphate levels were high (annual mean $0.64 \mathrm{mg} \mathrm{L}^{-1}$ ). In Lake Xochimilco, Nandini et al. (2016) reported nitrate levels of $<1 \mathrm{mg} \mathrm{L}^{-1}$, while phosphates are an order of magnitude higher $\left(2.5-7.8 \mathrm{mg} \mathrm{L}^{-1}\right)$. On the other hand, Chl $a$ levels in this work varied considerably (2 to $930 \mu \mathrm{g} \mathrm{L}^{-1}$ ), the mean annual concentration was $110 \mathrm{mg}$ $\mathrm{L}^{-1}$. High Chl $a$ levels were recorded in all sites during rainy months (July and August). Phosphate also showed peak values during this season, which is responsible for higher primary production in this waterbody (Moss, 2010). Based on Carlson's (1977) index of trophic state, this waterbody was eutrophic in all the stations during the entire sampling period.

Zooplankton in Madín reservoir was mainly composed of rotifers; crustaceans were represented by four taxa and cyclopoids n.d. Of the 28 rotifer taxa observed here, the family Brachionidae was dominant representing four genera and nine species. This is probably due to the high fish predation pressure (Gliwicz and Pijanowska, 1989; Hansson et al., 2007); this reservoir has high numbers of several fish species including carpa and tilapia. D. ambigua was common in winter months, while Diaphanosoma was in the summer months. This is supported by that fact that Daphnia is a temperate genus while Diaphanosoma is tropical (Forró et al., 2008). The occurrence of Mastigodiaptomus albuquerquenseis in this waterbody is no surprise since this genus is most common in Mexico with as many as 5 out of 10 known species are endemic to Mexican fauna (Gutíerrez-Aguirre and Cervantes-Martínez, 2016). We found four members of the genus Brachionus while Trichocerca was represented by just one species. In addition, Trichocerca was present in only two out of 12 months. Though we could not derive the $\mathrm{Q}_{\mathrm{B} / \mathrm{T}}$ quotient for Brachionus to Trichocerca (Sládeček, 1983) (Trichocerca was entirely absent for certain months), the data showed that the waterbody was eutrophic.

The dynamics of rotifer abundances in this waterbody showed seasonal trends which differ from the data reported from many other high-altitude waterbodies in the Central Mexico (Nandini et al., 2005; Gutiérrez et al., 2017). For example, most works have shown the dominance of Brachionidae (e.g., Keratella, Anuraeopsis) and Polyarthra (Jiménez-Contreras et al., 2009; FigueroaSanchez et al., 2014) in drinking water reservoirs, while in recreational waterbodies such as Llano Reservior, Trichocerca and bdelloids often dominate (MuñozColmenares et al., 2017). On the other hand, in shallow waterbodies such as Lake Xochimilco, species of Brachionus (B. calyciflorus, B. havanaensis, B. angularis and B. caudatus), Keratella (K. cochlearis, K. tropica) and Lecane (L. bulla) are dominant (Nandini et al., 2016; Gayosso-Morales et al., 2017). In deep lakes such as El Sol and La Luna the dominant rotifers are Polyarthra dolichoptera and Conochilus unicornis, bdelloids, Lecane lunaris and Lepadella accuminata (Dimas-Flores et al., 2008). Thus, in none of these studies, dominance of uncommon rotifers such as Horaella has been reported. In the present work, $H$. thomassoni reached density as high as 550 ind $\mathrm{L}^{-1}$. Earlier records indicate that this species occurs in much lower density $\left(150\right.$ ind $\left.\mathrm{L}^{-1}\right)$. In eutrophic waterbodies, cyanobacterial dominance is common. In this work, though phytoplankton analysis was not done, we observed high densities of Aphanothece sp. Aphanothece is a picocyanobacterium that produces toxins called nodularins. These nodularins are hepatotoxic cyclic peptides that are toxic to zooplankton (Ferrão-Filho and Kozlowsky-Suzuki, 2011). Interestingly during the blooms of Aphanothece, we also recorded higher densities of Horaella. It is possible that Horaella feeds on Aphanothece. Gut contents revealed freshly collected fragments of Aphanothece but could not be confirmed. However, based on the functional role, all species of Gnesiotrocha including Horaella, Filinia and Conochilus, possess malleoramate trophi, well adapted to feed on bacteria or detritus or other smaller food particles (Obertegger et al., 2011). Since Aphanothece belongs to picocyanobacteria, their cell size is within the preferred range of Gnesiotrocha. Laboratory studies indicate that several rotifers can feed well on cyanobacteria in spite of their poor nutritional quality or toxicity (Starkweather and Kellar, 1983; Alva et al., 2009).

The Madín reservoir has a high quantity of particulate organic matter since it receives domestic wastes containing organic substances. This is further confirmed by the Saprobic index of Pantle and Buck (1955), which ranged from 1.25 to 2.5 . Thus, the waterbody is oligosaprobic to $\beta$-mesosaprobic. This is similar to Lake Xochimilco with a saprobic index ranging from 1.5 to 2.0 (Nandini et al., 2016). The total rotifer density was however much lower: the mean annual density was 180 ind $\mathrm{L}^{-1}$ and when data of all the five stations were combined, 11 months had mean density of $<500$ ind $\mathrm{L}^{-1}$ 
(oligotrophic condition) while only one month (November) had close to 1000 ind $\mathrm{L}^{-1}$ (mesotrophic). Therefore, the use of total rotifer density as a parameter to determine the trophic state was not applicable to this reservoir, most probably due to the presence of inedible and possibly toxic picocyanobacteria (Aphanothece) and cyanobacteria (e.g., Microcystis). This is also possibly responsible for low species diversity $\left(<1\right.$ bits ind $^{-1}$ mean Shannon diversity), which is much lower than most waterbodies in this region (e.g., 1.2-3.4 bits ind $^{-1}$ : Xochimilco (Gayosso-Morales et al., 2017); 1.0-4.3 bits ind $^{-1}$ : Iturbide Reservoir (Sarma et al., 2011); 1.0-4.2 bits ind $^{-1}$ : Llano reservoir (Muñoz-Colmenares et al., 2017)). The mean annual TSI ${ }_{\text {ROT }}$ index for Madín reservoir was 38 indicating a mesotrophic condition of the waterbody (Ejsmont-Karabin, 2012). In a nearby high-altitude waterbody in Mexico City, Gutiérrez et al. (2017) reported that the mean annual $\mathrm{TSI}_{\mathrm{ROT}}$ index was $<40$, which is close to the value observed in the present study.

This study highlights the growth potential of Horaella thomassoni, Conochilus dossuarius and Cephalodella catellina. All these three species were able to reach up to 500 ind $\mathrm{L}^{-1}$ during winter. C. dossuarius was earlier reported at densities of up to 20 ind $\mathrm{L}^{-1}$ from the Lake Catemaco, a tropical waterbody from the State of Veracruz (Mexico) (Torres-Orozco and Zanatta, 1998). The growth potential of $C$. catellina is interesting. It is a small notommatid member (body length $<100 \mu \mathrm{m}$ ) and reached up to 1400 ind $\mathrm{L}^{-1}$ from site 4 during November. The genus Cephalodella is the most diverse of all rotifer genera with nearly $10 \%$ of all species (about 2000 taxa of global diversity). Though the reproductive biology of C. catellina is reported (Alvarado-Flores et al., 2017: Trophi of Fig. $3 \mathrm{E}$ shown in there does not belong to this species, possibly that of Notommata glyphura), its natural densities are generally low (Muñoz-Colmenares et al., 2017). Being very small, this species is also microphagous with an affinity to feed on small phytoplankton, bacteria and detritus abundant in the Madín Reservoir. Its high population density during blooms of Aphanothece suggests that it may be able to feed on this picocyanobacterium.

\section{CONCLUSIONS}

The growth potential of rotifers can be known based on field collections since culturing most of them under laboratory conditions is not possible due to unavailability of data on their and feeding habits. Our study showed that the seasonal study of Madín reservoir was helpful to understand the potential for high population densities of rotifers such as Horaella thomassoni, Conochilus dossuarius and Cephalodella catellina. For example, it was observed that Cephalodella catellina could reach peak density of up to 1400 ind $\mathrm{L}^{-1}$, while the rare species
Horaella thomassoni was capable of attaining peak population densities of more than 550 ind $\mathrm{L}^{-1}$. Our study further indicated that picocyanobacteria could be a potential source of food for Gnesiotrocha and smaller Cephalodella species. However, laboratory tests are still needed to confirm this and also the toxic nature of Aphanothece to rotifers.

\section{ACKNOWLEDGEMENTS}

This study forms part of the doctoral work of RMMG at UAM-I. Financial support received from CONACyT is gratefully acknowledged.

\section{REFERENCES}

Alcocer J, Bernal-Brooks FW, 2010. Limnology in Mexico. Hydrobiologia 644:1-54.

Alva-Martínez AF, Fernández R, Sarma SSS, Nandini S, 2009. Effect of mixed toxic diets (Microcystis and Chlorella) on the rotifers Brachionus calyciflorus and Brachionus havanaensis cultured alone and together. Limnologica 39:302-305.

Alvarado-Flores J, Guerrero-Jiménez G, Silva-Briano M, Adabache-Ortíz A, Delgado-Saucedo JJ, Pérez-Yañez D, Marín-Chan AG, DeGante-Flores M, Arroyo-Castro JL, Kordbacheh A, Walsh EJ, Rico-Martínez R, 2017. Sexual reproductive biology of twelve species of rotifers in the genera: Brachionus, Cephalodella, Collotheca, Epiphanes, Filinia, Lecane, and Trichocerca. Mar. Freshw. Behav. Phy. 50:141-163

Camargo JA, Alonso A, Salamanca A, 2005. Nitrate toxicity to aquatic animals: a review with new data for freshwater invertebrates. Chemosphere 58:1255-1267

Carlson RE, 1977. A trophic state index for lakes. Limnol. Oceanogr. 22:361-369.

Clesceri L, Greenberg A, Eaton AD, 1998. Standard methods for the examination of water and wastewater, $20^{\text {th }}$ ed. American Public Health Association: 1325 pp.

De la Lanza EG , García JLC, 2002. [Lagos y Presas de México].[Book in Spanish]. AGT Editor, Mexico City: 680 pp.

Dimas-Flores N, Alcocer J, Ciros-Pérez J, 2008. The structure of the zooplankton assemblages from two neighboring tropical high mountain lakes. J. Freshwater Ecol. 23:21-31.

Duggan IC, Green JD, Shiel RJ, 2002. Distribution of rotifer assemblages in North Island, New Zealand, lakes: relationships to environmental and historical factors. Freshwater Biol. 47:195-206.

Duran-Alvarez, JC, Prado B, Gonzalez D, Sanchez Y, JimenezCisneros B, 2015. Environmental fate of naproxen, carbamazepine and triclosan in wastewater, surface water and wastewater irrigated soil Results of laboratory scale experiments. Sci. Total Environ. 538: 350-362.

Edmondson WT, 1960. Reproductive rates of rotifers in natural populations. Mem. Ist. Ital. Idrobiol. 12:21-77.

Edmondson, WT, 1965. Reproductive rate of planktonic rotifers as related to food and temperature in nature. Ecol Monogr. 35:61-111. 
Ejsmont-Karabin J,1995. Rotifer occurrence in relation to age, depth and trophic state of quarry lakes. Hydrobiologia 313:21-28.

Ejsmont-Karabin J, 2012. The usefulness of zooplankton as lake ecosystem indicators: rotifer trophic state index. Pol. J. Ecol. 60: 339-350.

Espinosa-Rodríguez CA, Rivera-De la Parra L, Sarma SSS , Nandini S, 2014. Effect of food density of Pseudokirchneriella subcapitata and Chlorella vulgaris on the population growth rates of four brachionid rotifers. Inland Waters 4:271-278.

Ferrão-Filho AS, Kozlowsky-Suzuki B, 2011. Cyanotoxins: Bioaccumulation and effects on aquatic animals. Mar. Drugs 9:2729-2772.

Figueroa-Sanchez MA, Nandini S, Sarma SSS, 2014. Zooplankton community structure in the presence of low levels of cyanotoxins: A case study in a high altitude tropical reservoir (Valley de Bravo, Mexico). J. Limnol. 73:157-166.

Filho SJ, Neumann-Leitão S, Silva TA, Melo Júnior M, 2014. Planktonic rotifers from a tropical estuary under high marine influence (Passos River, PE, Brazil). Trop. Oceanogr. 42:68-79.

Fontaneto D, Melone G, 2003. On some rotifers new for the Italian fauna. Ital. J. Zool. 70:253-259.

Forró L, Korovchinsky NM, Kotov AA, Petrusek A, 2008. Global diversity of cladocerans (Cladocera: Crustacea) in freshwater. Hydrobiologia 595:177-184.

Gayosso-Morales MA, Nandini S, Martínez-Jeronimo FF, Sarma SSS, 2017. Effect of organic and inorganic turbidity on the zooplankton community structure of a shallow waterbody in Central Mexico (Lake Xochimilco, Mexico). J. Environ. Biol. 38:1183-1196.

Gliwicz ZM, Pijanowska J, 1989. The role of predation in zooplankton succession, p. 253-296. In: U. Sommer (ed.), Plankton ecology. Springer, Berlin.

González-González ED, Gómez-Oliván LM, Galar-Martínez M, Vieyra-Reyes P, Islas-Flores H, García-Medina S, JiménezVargas JM, Razo-Estrada C, Pérez-Pastén R, 2014. Metals and nonsteroidal anti-inflammatory pharmaceuticals drugs present in water from Madín reservoir (Mexico) induce oxidative stress in gill, blood, and muscle of common carp (Cyprinus carpio). Arch. Environ. Contam. Toxicol. 67:281-295.

González-Pérez BK, Sarma SSS, Castellanos-Páez ME, Nandini S, 2018. Multigenerational effects of triclosan on the demography of Plationus patulus and Brachionus havanaensis (Rotifera). Ecotox. Environ. Safe 147: 275-282.

Gutiérrez SG, Sarma SSS, Nandini S, 2017. Seasonal variations of rotifers from a high altitude urban shallow waterbody, $\mathrm{La}$ Cantera Oriente (Mexico City, Mexico). Chin. J. Oceanol. Limn. 35:1387-1397.

Gutiérrez-Aguirre MA, Cervantes-Martínez A, 2016. A new species of Mastigodiaptomus Light, 1939 from Mexico, with notes of species diversity of the genus (Copepoda, Calanoida, Diaptomidae). ZooKeys 637:61-79.

Inclan LAB, 1995. [Estudio limnológico de la presa Madín, Méx. Con énfasis en su estado trófico y en el manejo de cuenca].[Thesis dissertation in Spanish]. UNAM, Mexico City.

Hansson LA, Nicolle A, Brodersen J, Romare P, Skov C, Nilsson PA, Brönmark C, 2007. Consequences of fish predation, migration and juvenile ontogeny on zooplankton spring dynamics. Limnol. Oceanogr. 52: 696-706.
Jiménez-Contreras J, Sarma SSS, Merino-Ibarra M, Nandini S, 2009. Seasonal changes in the rotifer (Rotifera) diversity from a tropical high altitude reservoir (Valle de Bravo, Mexico). J. Environ. Biol. 30:191-195.

Koste W, 1978. [Rotatoria. Die Radertiere Mitteleuropas].[Book in German]. Borntraeger, Berlin: 673 pp.

Krebs JR, 1999. Ecological methodology. Harper Collins Publ., New York; 654 pp.

May L, O'Hare M, 2005. Changes in rotifer species composition and abundance along a trophic gradient in Loch Lomond, Scotland, UK. Hydrobiologia 546:397-404.

Montero-Pau J, Gabaldón C, Carmona MJ, Serra M, 2014. Measuring the potential for growth in populations investing in diapause. Ecol. Model. 272:76-83.

Moss B, 2010. Ecology of fresh waters: A view for the twentyfirst century. J. Wiley \& Sons, Oxford: $470 \mathrm{pp}$.

Muñoz-Colmenares ME, Sarma SSS, Nandini S, 2017. Seasonal variations of rotifers from the high altitude Llano reservoir (State of Mexico, Mexico). J. Environ. Biol. 38: 171-1181.

Nandini S, Ramírez-García P, Sarma SSS, 2005. Seasonal variations in the species diversity of planktonic rotifers in Lake Xochimilco, Mexico. J. Freshwater Ecol. 20:287-294.

Nandini S, Sarma SSS, Amador-López RJ, Bolaños-Muñoz S, 2007. Population growth and body size in five rotifer species in response to variable food concentration. J. Freshwater Ecol. 22:1-10.

Nandini S, Ramírez-García P, Sarma SSS, 2016. Water quality indicators in Lake Xochimilco, Mexico: zooplankton and Vibrio cholera. J. Limnol. 75:91-100. DOI 10.4081/jlimnol.2015.1213

Obertegger U, Smith HA, Flaim G, Wallace RL, 2011. Using the guild ratio to characterize pelagic rotifer communities. Hydrobiologia 662:157-162.

Orcutt JD Jr, Pace ML,1984. Seasonal dynamics of rotifer and crustacean zooplankton populations in a eutrophic, monomictic lake with a note on rotifer sampling techniques. Hydrobiologia 119: 73-80.

Osgood RA, 1982. Using differences among Carlson's trophic state index values in regional water quality assessment. Water Res. Bull. 18: 67-74.

Pantle R, Buck H, 1955. [Die biologische Uberwachung der Gewasser und die Darstellung der Ergebnisse].[Article in German]. GWF-Wasser/Abwasser 96:604-620.

Ramírez-García P, Nandini S, Sarma SSS, Robles-Valderrama E, Cuesta I, Hurtado-Maria D, 2002. Seasonal variations of zooplankton abundance in the freshwater reservoir Valle de Bravo (Mexico). Hydrobiologia 467:99-108.

Sarma SSS, 1991. Rotifers and aquaculture (Review). Environ. Ecol. 9:414-428.

Sarma SSS, Nandini S, 2002. Comparative life table demography and population growth of Brachionus macracanthus Daday, 1905 and Platyias quadricornis Ehrenberg, 1832 (Rotifera, Brachionidae) in relation to algal (Chlorella vulgaris) food density. Acta Hydrochim. Hydrobiol. 30:128-140.

Sarma SSS, Osnaya-Espinosa LR, Aguilar-Acosta CR, Nandini $\mathrm{S}, 2011$. Seasonal variations in zooplankton abundances in the Iturbide reservoir (Isidro Fabela, State of Mexico, Mexico). J. Environ. Biol. 32:473-480.

Sládeček V,1983. Rotifers as indicators of water quality. Hydrobiologia 100:169-201. 
Smith HA, Ejsmont-Karabin J, Hess TM, Wallace RL, 2009. Paradox of planktonic rotifers: similar structure but unique trajectories in communities of the Great Masurian Lakes (Poland). Verh. Internat. Verein. Limnol. 30:951-956.

Sokal RR, RohlfFJ, 2012. Biometry. The principles and practice of statistics in biological research. W.H. Freeman and Co., New York: 887 pp.

Starkweather PL, Kellar PE, 1983. Utilization of cyanobacteria by Brachionus calyciflorus: Anabaena flos-aquae (NRC-441 ) as a sole or complementary food source. Hydrobiologia 104:373-377.

Torres-Orozco RE, Zanatta SA, 1998. Species composition, abundance and distribution of zooplankton in a tropical eutrophic lake: Lake Catemaco, México. Rev. Biol. Trop. 46:285-296.
Wallace RL, Snell TW, Ricci C, Nogrady T, 2006. Rotifera, Part 1: biology, ecology and systematics. SPB Academic Publ., Amsterdam: 299 pp.

Wallace RL, Snell TW, Walsh EJ, Sarma SSS, Segers H, 2016. Phylum Rotifera, p. 131-167. In: J.H. Thorp and D.C. Rogers (eds.), Keys to Nearctic fauna. Thorp and Covich's Freshwater Invertebrates. Elsevier, Amsterdam.

Wen X, Zhai P, Feng R, Yang R, Xi Y, 2017. Comparative analysis of the spatio-temporal dynamics of rotifer community structure based on taxonomic indices and functional groups in two subtropical lakes. Sci. Rep. 7:578.

Yoshimatsu T, Hossain MA, 2014. Recent advances in the high-density rotifer culture in Japan. Aquacult. Int. 22:1587-1603. 